\title{
Legal production of illegality in a comparative perspective. The cases of Malaysia and Spain
}

\author{
Blanca Garcés-Mascareñas
}

Published online: 30 May 2010

(C) The Author(s) 2010. This article is published with open access at Springerlink.com

\begin{abstract}
Most studies on illegal migration focus on particular national or local settings and most theoretical approaches are built upon research done in America and Western Europe. In consequence, there is little understanding about the legal construction of the 'illegal' and the meanings of migrants' illegality in different political contexts. Given these major shortcomings, this article compares the cases of Malaysia and Spain. By comparing how we can explain illegal immigration and what it means to be illegal in each country, the final aim of this article is to place the term 'illegal' back into its context, that is, to understand the 'illegal' not as an essentialised, generic and singular object but rather as a legal and political product of particular historical and national contexts.
\end{abstract}

\section{Introduction}

Illegal migration has become a permanent phenomenon in many countries. The International Organisation for Migration estimates that illegal immigrants may account for one third to one half of new entrants into developed countries, marking an increase of $20 \%$ over the past 10 years. In the European Union alone estimates suggest that the inflow might amount to 500,000 illegal migrants annually. Although there are no estimates at the regional level for Southeast Asia or Asia in general, countries such as Malaysia, Taiwan, Japan or India experience high levels of illegal migration from other neighbouring countries. In Malaysia alone, for instance, one million illegal migrants (in a population of 27 million) have been estimated in the past years. Following this development, illegal migration has become prominent, if not foremost, in much contemporary academic and public debate as well as policy thinking around migration. In Europe and Asia it is receiving wider attention as

B. Garcés-Mascareñas $(\bowtie)$

Institute for Migration and Ethnic Studies (IMES), University of Amsterdam, Het Binnen Gasthuis,

Room 0.25, Oudezijds Achterburgwal 237, 1012 Amsterdam, The Netherlands

e-mail: B.GarcesMascarenas@uva.nl

e-mail: blancagarcesmas@yahoo.es 
stricter measures are being adopted to reduce it. New initiatives are also being taken to supplement or reinforce existing regional and international instruments dealing with different aspects of illegal migration.

Despite its central place on national and international agendas and academic debates, most studies on illegal migration focus on particular national and local settings, and most theoretical approaches are built upon research done in North America and Western Europe. These two features are at the basis of the two main pitfalls of the literature on illegal migration. First, there is little understanding about the legal and political construction of the 'illegal' and how this relates with particular politics of nationalism and citizenship or, more broadly, with the constantly redefined boundaries of particular nation-states. Second, migrants' illegality is often understood as if it was the same everywhere. However, as debated and shown in the ASEF Workshop on illegal migration in Asia and Europe (Kuala Lumpur, January 2008), illegal migration differs in many ways. It differs in the way it is produced. For instance, in countries with very restrictive migration policies, illegal migration results in great measure from the impossibility to enter the country legally. It also differs in the way it is defined. Although the illegal migrant is seldom defined in national law (Guild 2004), migration policies place the illegal migrant in very different situations. For instance, while in some countries illegal migrants are completely ignored or refused as social and political subjects, in other countries they are entitled to work or have access to health care and education.

Given these major shortcomings, this article compares the cases of Malaysia and Spain. These two countries are similar in that both countries have had a huge demand for foreign labour in the last two decades. At the same time, they are different in the way how their governments have responded to these demands. While Malaysia launched a guest worker programme from the early 1990s on, Spain opted to implement a rather restrictive entry policy. Despite this diversity, both countries have experienced sizeable illegal migration flows. Given these similarities and differences, a question emerges about how we can explain illegal immigration and what illegal means in such different policy contexts. By considering these two questions, this article aims to place the term illegal migrant back into the context, that is, to understand the 'illegal' not as an essentialised, generic and singular object but rather as a legal and political product of particular historical and national contexts.

\section{Law and illegal migration}

The link between law and illegal migration has been commonly observed. The most common approach has been to explain illegal immigration as a result of an ineffective and powerless law. Internalising the mores and norms of the modern state by portraying the law as a force that bars illegal entry and sojourn rather than as a process that defines who and what is illegal (Coutin 1996: 11), this approach focuses on the degree to which policies are capable of stemming illegal immigration. In consequence, the conclusion is simple: illegal migration proves the ineffectiveness of migration policies. In other words, if illegal migration continues to 'take place' and 'illegal migrants' continue 'to be' present in contemporary societies despite increasing border enforcement and more internal control, this means that policies 
do not work. This perceived failure of migration policies (or gap between policy goals and outcomes) is explained by referring to the high cost of enforcement, the economic role of illegal labour, the public unwillingness to punish migrants' illegality or the strength of the macro-structural forces of migration (Cornelius and Tsuda 2004: 9).

A second way to approach this link has been by focusing on how the law serves the interests of powerful economic and political groups, basically the need of capitalists and capitalism. From this perspective, migration policies are not analysed in their attempt to reduce illegal migration but rather in their function to place illegal migrants in a more exploitable position. In other words, the criminalisation of illegal migrants is understood as a way to construct and preserve the immigrants' otherness on which their condition as a cheap and flexible labour force rests (Portes 1977: 474; Sassen 1988: 7; Calavita 2005: 46). Finally, in a less deterministic way, more recent studies have initiated what we could call a third approach to the legal production of migrants' illegality (De Genova 2002; Coutin 2000; 2005). The question here is how immigration law constitutes individuals within immigration categories. In this regard, more effective migration policies do not mean less illegal migration (as assumed by the first set of studies) but rather an improvement on the state's ability to constitute categories of differentiation. The law creates thus the subjects that on the surface it seeks to bar. Whether these subjects constitute a cheap and flexible labour force is more an empirical question than a starting point of inquiry.

If the law creates the category of the illegal, the following question is what does it mean to be categorised as 'illegal'. Following Coutin, illegality means 'a space of forced invisibility, exclusion, subjugation and repression' (Coutin 2000: 30). This non-existence is imposed to migrants by dimensions such as the delimitation of reality to that which can be documented; the temporalisation of presence, being the possibility of regularisation dependent on being able to prove their illegal residence; 'legal aconsanguinity', as certain kinship ties are nullified by immigration policies; 'enforced clandestinity'; and restricted physical and social mobility (Coutin 2000: 30-33). In a similar way, De Genova (2002: 438-439) defines migrants' illegality as that space determined by a palpable sense of deportability, that is, by the possibility of being removed from the space of the nation-state. What defines illegality is not deportation but rather the possibility of deportation, that is, the fact that some are deported while most remain (undeported). According to De Genova, this deportability reproduces the physical borders of nation-states in the migrants' everyday life and, by so doing, constructs a spatialised and racialised social condition that would indeed sustain the vulnerability and tractability of illegal migrants as workers.

By focusing on the legal construction of 'illegality' as immigration category, this third approach reveals as well how immigrants themselves use law to claim, contest and reject these legal identities. In her study on Salvadorian migrants in the USA, Coutin (2005: 23) observes how they challenge the attribution of illegality by arguing that they migrated to the United States out of necessity, that they were participating and thus were integrated in US society or that the US economy benefited from their labour. Similarly, Kyle and Siracusa (2005) show how Ecuadorian migrants in Spain were aware of breaking immigration law but rejected the idea that this made their venture illegal. To justify it, these migrants referred to the responsibility of the Ecuadorian state elite, defined as a powerful mafia running a 
predatory state, and to the historical responsibility of Spain as coloniser of Latin America. In other words, using Van Schendel's and Abraham's terms (2005), their main claim was that their movement and stay in Spain was illegal but licit, that is, considered illegitimate by the state but claimed as legitimate by themselves. While these authors have noted how the attribution of illegality has been contested by migrants' discourse, other scholars have focused on how individual and collective coping strategies of the migrants themselves, non-governmental organisations and sympathetic civil servants have opened up loopholes for illegal immigrants in an increasingly protected job market or welfare state (for instance, see van der Leun 2003).

Although this third approach has brought important insights on the (contested) meanings and implications of migrants' illegality, it has shifted the focus away from the causes underlying illegal migration. Trying to bring it back, the question that remains to be answered is how to explain illegal migration. Is illegal migration, as argued by Cornelius and Tsuda, a result of ineffective, failed or inherently flawed immigration policies? Is illegal migration, as argued by Portes, Sassen and Calavita, a way to create a cheap and flexible labour force? Another question that remains to be considered is whether illegal migration 'exists' and 'is' the same everywhere. Most approaches on illegal migration assume that illegality leads to the most subordinated form of legal existence (basically because of the non-legal existence of illegal migrants) and therefore to the cheapest and most flexible type of labour force. The logic behind this argument is that the more illegal a migrant is, the less rights (thus the more vulnerable position) he or she has. However, as we will see in this article, this correlation does not seem to apply everywhere. Since the contours of illegality mirror those of legality, the meaning of illegality depends on that of migrants' legality.

\section{Two different labour migration policy models}

Both Malaysia and Spain have presented huge foreign labour demands since the late 1980s on. Given these demands, both states have responded by setting up particular migration policies. In the case of Malaysia, these policies have sought to open entry while restricting membership. As has happened with any other guest worker programme, the Malaysian State did not restrict the entry of migrant workers but has placed limits on time of residence, position in the labour market and social and labour rights. In contrast, the Spanish State opted for a particularly restrictive entry policy until 2005. While demands for labour kept growing throughout the 1990s, the government did not respond accordingly by adjusting its immigration policy to let in greater numbers of workers. Hence, in Spain there was a clear contrast between the economics and politics of immigration.

In order to explain the high-numbers policy in Malaysia one would need to refer not only to the role of employers in immigration policymaking but also to the development-oriented project of the State of Malaysia. The New Economic Policy (1971-1990), and its subsequent derivations, sought to restructure the legacy of colonial society by means of promoting economic growth. While social programmes aimed at situating the Malay in a better position in the labour market, economic 
growth continued to depend on cheap labour. In this context, there was (and there still is) general consensus that employment of migrant workers was necessary for both social stability and economic growth. In Spain, in contrast, the nature of immigration policies arose from very different priorities. First, the demand for closure was determined by European Union requirements. Second, given that unemployment figures had risen to over $20 \%$ by the mid-1990s, immigration policies tended to guarantee protection for national workers more than to heed the employers' demands. Finally, some of the restrictive aspects of Spanish immigration policy should be understood in relation with the fact that the policies did not work well and, more specifically, with the slowness of procedures and the-politicallymuch-vaunted myth of recruitment in the countries of origin.

However, to conclude that Malaysia is characterised by an open entry policy and Spain by a restrictive one would mean remaining on the surface of things or settling for an analysis of written policy and its implementation without inquiring into its effects. This distinction between the law in the books and the law in practise is especially significant in the Spanish case. In Malaysia, the immigration policies produced what they claimed, in other words, many immigrants with very few rights. The opposite happened in Spain. Despite the restrictiveness of its immigration policies, immigrants kept coming in all the same. As many scholars and the stakeholders themselves (starting from the leading political parties) have noted, the mismatch between significant demands for foreign labour and highly restrictive entry policies led to an out-and-out model of illegal immigration (Izquierdo 1996: 37; Solanes 2001: 82; Arango and Sandell 2004: 25; Calavita 2005: 12; Finotelli 2007: 3). In this regard, if one focuses on how the labour demands were covered in practise, one would conclude that, in Spain, too, the demand for labour led to a situation of high numbers and low rights: high numbers in the sense that employers got as many migrant workers as wanted; low rights in the sense that, in their capacity as 'illegal', immigrant workers entered the country and worked without having a legal existence, which means without minimal social and labour rights, and without the fact of their presence affording access to permanent residence or citizenship. In short, as with the case of workers in Malaysia, those in Spain also 'entered' but, once 'inside', they were still 'outside' in any social, labour-related and symbolic sense.

Joint analysis of entry policies and regularisation programmes would, in fact, lead one to a similar conclusion, although there is one further nuance. The Spanish regularisation programmes operated for a long time as the real entry policy. Until 2005, legal entry (as an immigrant worker) was so difficult that people usually entered the country, stayed on and worked illegally until eventually becoming regularised. In this regard, one might conclude that, while entry policies were particularly restrictive, the mechanisms of regularisation ended up making entry relatively open. However, entry via regularisation has always meant deferment since an immigrant could only opt for regularisation if he or she had been illegal. Making illegality a requisite for legality meant that those who entered the country had to come in with very few rights. As noted above, this was a policy of high numbers and low rights. The difference in this case is that once they were regularised and after some years of conditional residence, most of the immigrants ended up obtaining a permanent residence permit or even Spanish citizenship. In other words, in the long 
term, the regularisation policy eventually led to a situation of high numbers and high rights.

Finally, to conclude this account of the Spanish model, 2005 represented a major change in policy. Along with a final regularisation process that involved almost 700,000 applications, the government finally switched to a relatively open entry policy. The main reason for this, as had repeatedly been proclaimed by the government (of different political parties) in the previous few years, was the aim of legally channelling immigration so as to cut down the numbers of illegal immigrants. In fact, the combination of illegal immigration and the periodical regularisation processes could not continue ad infinitum without undermining the legitimacy of the state inasmuch as it had to be seen to be fulfilling its role of controlling immigration flows. Accordingly, in order to avoid what we might define as continuous correction of a non-functioning migratory system, the government at last opted for an entry policy that was more visibly in keeping with demands for foreign workers. The result was a policy of high numbers and conditioned rights which, over the years, led as well to a situation characterised by high numbers and high rights.

\section{The state's production of illegality}

Despite so different labour migration policy models, both Malaysia and Spain are clear examples of a state's production of illegality. By the state's production of illegality I do not mean, as other authors have argued (see, for example, Calavita 2005), that the non-legal recognition of the immigrant's existence and work seeks to create a cheap, flexible labour force. It is true that borders might be instrumental in this. Yet the state's production of illegality is much more than this. It is linked with the intractable antagonism between demands for migrant labour and demands for closure. Attempts have been made to find a solution to this dilemma in both Malaysia and Spain: in Malaysia by limiting rights instead of numbers, in Spain by limiting numbers instead of rights. In both cases, these attempts have been made with the conviction and intention that migrant labour could be 'imported', controlled, limited and, where necessary, 'exported' at will. However, labour is not, and never has been, just a commodity. In neither of the two cases, with or without rights, has the state succeeded in commodifying migrant labour. The first and foremost result of this 'failed' attempt has been the creation of the illegal immigrant or what others (see Cornelius and Tsuda 2004) have dubbed a gap between migration policies and outcomes.

In the Malaysian case, illegality has been the result, first, of a bureaucratised and commercialised border. Entering Malaysia as a foreign worker has involved a great deal of red tape and paying out for an endless series of papers with the governments in the countries of origin as well as the Malaysian embassies. Moreover, the existence of a chain of intermediaries (the so-called recruitment agencies) has only increased the costs of a journey which, for people just across the border, are exorbitant and unnecessary. Due to the bureaucratisation and commercialisation of the border, illegal entry has represented for would-be immigrants in nearby zones a much faster and cheaper option. Second, control over immigrants has clashed with the interests of employers who want a more flexible and also permanent workforce, 
that means, access to foreign labour whenever and for as long as required. Then again, there is the resistance of immigrants to being turned into a flexible and temporary labour to be imported and exported at will (see Garcés-Mascareñas 2006, 2008).

In the case of Spain, the state's production of illegality resulted from two different processes. First, as noted above, the mismatch between the economics and politics of migration led to nothing less than an outright model of illegal immigration. This mismatch is related with the national interest of the restrictionist but also with a bureaucracy that was unable to cope with burgeoning and 'unforeseen' requests for entry. Second, the policy of periodical regularisations both reduced and produced illegality. If each regularisation campaign was launched with the aim of taking the illegality count back to zero, each regularisation process produced new or recurrent illegality. This must be explained by the fact that until 2001 time of residence rather than holding a job was the main requisite for regularisation, while with the first renovation after a year holding a job rather than residence was the chief requirement for maintaining legal status. What ended up creating illegality, then, was the combination of relative (though deferred) open entry by means of regularisation and the preservation of a form of conditioned membership. In other words, illegality (or what Spanish scholars have called 'relapse into illegality') was the aftermath of a regularisation policy that applied to residents and a renovation policy that only covered workers with a (formally recognised) job.

It might be asserted that any kind of regulation entails its opposite or, to put it slightly differently, legality bears illegality within it. While this may be true, I wish to take the argument somewhat further. In particular, this study shows how it is precisely 'the illusion' of considering and treating immigrants only as workers, as manpower that can be imported, kept under constraints and exported at will, that produces this illegality. The reason for this is simply that the condition of immigrants is much more than that of mere bracero (arm-men in English) or of a commodity that can be subjected to barriers, tariffs and limits. This does not mean that borders and state control do not matter. In fact, illegality is proof of their existence and relevance. It means, rather, that illegality - and this is the main thrust of my argument - should not be explained in outside terms but from within, from the context of immigration policy itself and the contradictions besetting the nation-state with regard to labour demands.

\section{Meanings of illegality}

The literature on migrants' illegality focuses on two main issues. On the one hand, some scholars analyse the implications of legal exclusion with regard to illegal immigrants' lives. These writers speak, for example, of how the category of 'illegal' tends to construct a subordinate labour force, pure manpower without access to social services and facilities, or non-legal subjects (homo sacer, in Giorgio Agamben's words), a status under which everything (or almost everything) would seem possible. On the other hand, different authors have brought out the ways in which illegal immigrants are incorporated through informal, every day practises. This strand of the literature is concerned with how individual and collective coping 
strategies, of the migrants themselves, non-governmental organisations, and sympathetic civil servants have paved the way for an opening up of loopholes for illegal immigrants in the job market or in the realm of the welfare state. From a comparative standpoint, the present study is a blend of both types of research.

With regard to the first matter, suffice to say that illegality does not always mean confinement to a subordinate identity or imprisonment within the bounds of nonrecognition. Better said, it is not always more the case than it is with legality. In Malaysia, the resort to illegality, both by people who entered the country illegally and those who became illegal immigrants on leaving their employers, has made it possible for people to 'escape' the restraints imposed by the state-regulated migrant labour system. To be more concise, illegal immigrants, unlike 'legal' immigrants, can change jobs, can to some extent negotiate their salary and working conditions, do not have to pay extra to enter or remain in the country and can prolong their stay independently of the economic situation or their state of health, or beyond the 5 years stipulated by law (Kassim 1995: 12-15; Wong and Anwar 2003: 220). In this regard, and in contrast with what has been observed in Europe and the United States, illegality can also constitute a form of resistance. A form of resistance that is, in fact, not so different from the kinds of resistance adopted by Malay peasants as described by James Scott (1985). This resistance is not organised or collective by nature and neither is it verbalised or staged in any way, but rather it is carried out on the basis of small, everyday, individual actions, on the basis of leading an invisible-or invisibilised-existence which, precisely as such, contrives to escape from, and thereby reveal itself to, state control.

As for the dichotomy between exclusion in the formal sphere and inclusion in the informal one, the Spanish case is paradigmatic in the way its legal system at once excludes and includes. By this I mean the way in which 'the tension between illegal status and certain citizenship rights does not always set up an opposition between formal law, on the one hand, and informal practises, on the other: it is always located within the law itself' (Chauvin and Garcés-Mascareñas forthcoming). First of all, while illegal immigrants are undocumented on the national level (by the central government), their registration in the municipal census (in Spanish, el padrón) documents them at the local level. Second, while legal and political processes were including illegal immigrants in some spheres of the social domain, in terms of work, they still fell into the category of legally non-existent, and hence right-less manpower. This flexible line between exclusion and inclusion, between outside and inside, reveals how illegality should be understood as a differentiated form of inclusion rather than as absolute shutting out. Furthermore, it makes it possible to identify the more sheltered or protected aspects of citizenship. In particular, in the Spanish case, it would seem clear that the borderlines that affect illegal immigrants are much less permeable in the national domain and with respect to the labour market than in the local domain and with respect to the welfare state.

Finally, if we compare the meanings of illegality in Malaysia and Spain, it is important to identify a number of major differences and similarities. If illegality is defined as an in-between state of regularise ability (the possibility of being regularised) and deportability (the possibility of being deported), we could conclude that the situation of illegal immigrants would tend more to deportability in Malaysia and more to regularise ability in Spain. Another difference between the two countries 
is connected with the relationship between legality and illegality. In Malaysia, illegality should be understood above all as an alternative to legality (with regard to both arrival and stay) while in Spain it is more like a path or form of access to legality. This is to say that, in contrast with Malaysia, illegality in Spain has ended up representing a transition, path or requisite for legality. Despite all these fundamental differences, both cases make it clear how legal status and illegal status are not fixed. On the contrary, immigrants move from one status to the other (from legality to illegality in Malaysia, and from illegality to legality and vice-versa in Spain) with relative ease. Finally, in both cases, one can see that to speak of illegality is also to speak of what might be called the theatre of illegality, which is to say, of the staging of migratory control over the illegal immigrant.

As De Genova (2002: 436-437) has made clear for the case of the United States, this staging (or show) of migratory control is mainly carried out by means of arrests, detentions and deportations. It is by deprivation of free movement and forced physical expulsion that state control is deployed in its most heightened expression. If in the sphere of labour the illegal immigrant is stripped of his or her rights as a worker, with deportation he or she is directly dispossessed of freedom of movement (De Genova 2009). The aim of deportation policies is not so much to reduce illegal immigration as to delimit a symbolic precinct of illegality. While this is common to both Malaysia and Spain, the basic difference between the two countries is to be found in the geographic domain or space in which the illegality show is staged. In Malaysia, deportation policies are put into practise at the very heart of national territory. In Spain, they are carried out in particular on the geographic frontier and beyond. This difference between the geographies of deportability suggests that the deportees are different in each case. In Malaysia, essentially workers are deported, while in Spain deportation is mostly applied - and one might almost say in a preventive fashion - to those who have not yet managed to get in.

\section{Toward a theory of borders and confines}

A comparison between two such different countries (which, however, are much more alike than one might expect), clearly shows how borders act in very different ways or, to be more specific, have different implications and meanings when considered in the light of migratory flows. Although this factor goes well beyond the scope of this study, I would like to sketch what we might call an incipient theory of borders and confines. By border I understand the territory where one state ends and another begins, or the geographic line between different states. By confine I mean, using the term and definition of Mezzadra (2005: 112), the 'line of division and protection of constituted and consolidated political, social and symbolic spaces'. Thinking about borders and confines from a comparative point of view, this study shows that what is engraved on the experience of immigrants is mainly the confine in the case of Malaysia and mainly the border in that of Spain.

In Malaysia the geographic border is not erected as a wall separating those inside from those outside. Through the country's airports or aboard small boats, legal and illegal immigrants cross the borders of Malaysia without much difficulty. Once they 
are inside, however, the confine is imposed on both groups. In the case of legal immigrants, the confine is established when they are immobilised in the job market, made dependent on their employers, and defined as purely and exclusively temporary labour. In brief, the confine of legality is marked by the idea of reducing legal immigrants to the condition of being mere 'foreign workers'. As for illegal immigrants, the confine is constructed over the threat of deportation, or the possibility of being physically 'expelled' from national territory in a more than less judicial and more than less arbitrary fashion. In this regard, we might conclude, as I have argued elsewhere (Garcés-Mascareñas 2010), that what marks the experience of immigrants is not so much crossing the border (legally or illegally) as being on the outside even when physically inside.

In Spain - and this point can be extended to most Western countries - it is especially on the border where the largest scale and most frequent forms of exclusion occur. It is at the border, and even beyond it, in the countries of origin, where the meagre trickle of those who may enter are separated from those who may not or where those who seem to be trying to get in anyway are rejected and turned back. In other words, in contrast with Malaysia, it is especially on the border where not only the illegality show is staged but also the ultimate performance of immigration policies. In fact, the dominance of the border over the confine is a form of excluding immigrants where exclusion is still possible, which is to say, where the state can still get around the constraints imposed by the legal and political systems. From this point of view we might conclude that the relationship between border and confine is not only connected with the nature of the nation-state (in the post-colonial states such Malaysia frontier territories have remained to a large extent at a great remove from the interests of the national elites installed in the centre) or with the greater influence of factor markets in migration policymaking processes (favouring the entry of workers) but also with the role played by rights (and their application) within national territory.

It would be too simple to conclude, however, that the confine is characteristic of non-democratic or autocratic countries while the border is imposed as the only form of exclusion in liberal democracies. On the one hand, in Spain there are also significant confines that affect both legal and illegal immigrants. The difference with Malaysia does not lie so much in the existence or absence of the confine but rather in its duration. In other words, the important fact is not that, in Spain, there has been no exclusion from within, but that it has only been possible to enforce this exclusion during the first years in the country. In the long term, both legal and illegal immigrants have ended up being recognised as permanent residents or fully fledged citizens. On the other hand, several studies (Balibar 2001; Bigo 2002; Salter 2004; Mezzadra 2005; Walters 2006) have signalled an increasing tendency towards 'delocalisation', 'de-territorialisation' or 'disegregation' from the border inwards. Hence, along with the reinforcement of exterior walls and the externalisation of the border towards the countries of origin, another 'border that is implosive, infinitely elastic, and in effect, truly everywhere, within the space of the nation-state' (De Genova 2009: 30) would also be under construction. It remains to be seen how far it is possible to go with this exclusion from within, and to what extent rights, or the rule of law, do play the fundamental role that many have attributed to them. 


\section{Conclusions}

States are confronted with a dilemma when regulating labour migration: while markets require a policy of open borders to provide as many migrant workers as demanded, citizenship seems to require some degree of closure to the outside so as to protect the economic, social, political and cultural boundaries of the nation-state. As pointed out by Bader (1995: 212), the tendency toward universalist inclusion within states is intrinsically interwoven with systematic exclusion of those categorised as non-members, non-citizens or foreigners. While in Malaysia this dilemma between markets and citizenship was attempted to be solved by limiting rights instead of numbers, in Spain this was done by limiting numbers instead of rights. Despite this difference, both states have operated under the assumption that this dilemma could be solved by 'managing' immigration as an economic matter, that is, by considering immigrants as pure labour that could be subjected to multiple barriers. However, in both cases this has proven to be an illusion that ended up in what I described as state's production of migrants illegality. From this perspective, illegal migration is thus not the consequence of ineffective, failed or inherently flawed immigration policies but rather the result of the intractable antagonism between demands for migrant labour and demands for closure.

While both Malaysia and Spain are clear examples of the state's production of migrants' illegality, the second question to be considered is what illegality means. The comparison between both cases allows us to reconsider current conceptualisations on illegal migration. First, illegality mirrors legality. While in the case of Malaysia illegality makes it possible for migrants to escape the restraints imposed on legal migrants, in Spain illegality has been the mainly path to later access to legality. In other words, in Malaysia illegality often represents a way to escape from State control. In Spain, illegality is presented as a sin demanding reparation (thus legal recognition) through good moral and economic performance (see Chauvin and Garcés-Mascareñas forthcoming). Second, deportation policies delimit the symbolic precinct of illegality in both cases and, in consequence, the boundary that places 'illegals' as definitively outsiders or deportable subjects. While in Malaysia this boundary is placed within the national territory, in Spain rights' constraints have displaced the exercise of this symbolic precinct at the margins of the territory, that is, at the geographic borders and beyond. This means that while in Malaysia deportation is exercised upon migrant workers, in Spain this is mainly imposed on those who have not yet managed to get in. Once they are in, illegality is not anymore synonymous with deportability but rather becomes a form of subordinated inclusion in the long and often winding path toward legality.

Open Access This article is distributed under the terms of the Creative Commons Attribution Noncommercial License which permits any noncommercial use, distribution, and reproduction in any medium, provided the original author(s) and source are credited. 


\section{References}

Arango J, Sandell R (2004) Inmigración: prioridades para una nueva política española. Instituto Universitario Ortega y Gasset, Madrid

Bader V (1995) Citizenship and exclusion. radical democracy, community and justice. or, what is wrong with communitarism? Polit Theory 23(2):211-246

Balibar É (2001) Nous, citoyens d'Europe? Le frontières, l'État, le peuple. La Découverte, Paris

Bigo D (2002) Security and immigration: toward a critique of the governmentality of unease. Alternatives 27(1):63-92

Calavita K (2005) Immigrants at the margins. Law, race and exclusion in Southern Europe. Cambridge University Press, Cambridge

Chauvin S, Garcés-Mascareñas B (forthcoming) Beyond informal citizenship. Regimes of Migrant illegality in Cross-National Perspective. IMES Working Paper

Cornelius W, Tsuda T (2004) Controlling immigration: the limits of government intervention. In: Cornelius WA et al (eds) Controlling immigration. A global perspective, 2nd edn. Stanford University Press, Standford

Coutin SB (1996) Differences within accounts of U.S. immigration law. PoLAR 19(1):11-20

Coutin SB (2000) Legalizing moves: Savadoran immigrants' struggle for US residency. University Michigan Press, Ann Arbor

Coutin SB (2005) Contesting criminality: illegal immigration and the spatialization of legality. SAGE Publications, London

De Genova N (2002) Migrant 'Illegality’ and deportability in everyday life. Ann Rev Anthropol 31:419-447

De Genova N (2009) The deportation regime: sovereignty, space, and the freedom of movement. Duke University Press

Finotelli C (2007) Italia, España y el modelo migratorio mediterráneo en el siglo XXI, ARI 58

Garcés-Mascareñas B (2006) Produciendo 'ilegales'. Políticas de inmigración en Malasia, Revista Española de Investigaciones Sociológicas, 116

Garcés-Mascareñas B (2008) Producing irregularity, constructing illegality, deporting migrants. Migration policies in Malaysia, paper presented at the ASEF workshop 'Now you see them, now you don't. Defining irregular migrants in Europe and Asia and the immigration measures applied to the', 7-9 January, Kuala Lumpur

Garcés-Mascareñas B (2010) Fronteras y confines de un estado post-colonial. El caso de Malasia. In: Anguiano ME, López Sala A (eds) Migraciones en territorios de frontera. Icaria/CIDOB, Barcelona

Guild E (2004) Who is an irregular migrant? In: Bogusz B, Cholewinski R, Cygan A, Szyszczak E (eds) Irregular migration and human rights: theoretical, European and international perpsectives. Martinus Nijhoff Publishers, Leiden and Boston

Izquierdo Escribano A (1996) La inmigración inesperada. Trotta, Madrid

Kassim A (1995) Foreign Workers in Malaysia: an Analysis of Sanctioned Bondage, paper presented at the Regional Conference of the International Council of Psychologists on 'Psychological Issues in a Growing Global Community', 10-12 August, Manila

Kyle D, Siracusa CA (2005) Seeing the state like a migrant: why so many non-criminals break immigration laws. In: van Schendel W, Abraham I (eds) Illicit flows and criminal things. states, borders, and the other side of globalization. Indiana University Press, 153-177

Mezzadra S (2005) Derecho de fuga. Migraciones, ciudadanía y globalización. Traficantes de Sueños, Madrid

Portes A (1977) Labor functions of illegal migrants. Society 14(6):31-37

Salter M (2004) Passports, mobility, and security: how smart can the border be? Int Stud Perspect 5:71-91

Sassen S (1988) The mobility of labor and capital: a study in international investmetn and labor flow. Cambridge University Press, Cambridge

Scott JC (1985) Weapons of the weak: everyday forms of peasant resistance. Yale University Press

Solanes A (2001) Sujetos al margen del ordenamiento jurídico: los inmigrantes sin papeles. In: Lucas J, Peña S, Solanes A (eds) Inmigrantes: una aproximación jurídica a sus derechos. Germania, Valencia

Van der Leun J (2003) Looking for loopholes. Processes of incorporation of illegal immigrants in the Netherlands. Amsterdam University Press, Amsterdam 
Van Schendel W, Abraham I (2005) (eds) Illicit flows and criminal things. States, borders, and the other side of globalization. Indiana University Press, Indiana

Walters W (2006) Border/control. Eur J Soc Theory 9(2):187-203

Wong DT, Afrizal Teuku Anwar T (2003) Migran Gelap: Indonesian migrants in Malaysia's irregular labour economy. In: Battistella G, Asis MB (eds) Unauthorised migration in Southeast Asia. Scalabrini Migration Centre, Manila

This research has been financed by the Agencia Española de Cooperación Internacional (AECI), the Netherlands Organisation for Scientific Research (NWO), the Centrum voor Migratierecht (Radboud Universiteit Nijmegen), the Institute for Migration and Ethnic Studies (University of Amsterdam) and the Fundació Jaume Bofill. I would like to thank Rinus Penninx, Kees Groenendijk, Tesseltje de Lange and Wouter Tebbens for their comments on this article. I am particularly thankful to Julie Wark and Aimee Rindoks for their English language revision. 